\title{
Metaplastic Carcinoma of the Breast: Analysis of 38 Cases from a Single Institute
}

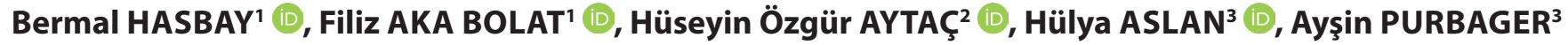

Department of ${ }^{1}$ Pathology, ${ }^{2}$ General Surgery and ${ }^{3}$ Radiology, Başkent University, Dr. Turgut Noyan Application and Research Center, ADANA TURKEY

\begin{abstract}
Objective: To evaluate the pathological and radiological features, hormone profiles, surgery and treatment methods of metaplastic breast carcinoma cases diagnosed at our center in the light of current literature.

Material and Method: A total of 38 metaplastic breast cancer cases diagnosed between 2006-2018 at our center were included in the study. The patients were evaluated in terms of age, tumor size, localization, histological grade, hormone profiles (ER, PR, Her2-neu), American Joint Committee on Cancer (AJCC) Tumor, Lymph node status, Metastases (TNM) stage, progression, survival, radiological features, types of surgery and therapy modalities (chemotherapy and / or radiotherapy).

Results: The age of the patients ranged between 32 and 95 years. Pathological evaluation of cases showed that 14 were pure epithelial (IC-NST + squamous cell carcinoma) and 24 were metaplastic carcinomas with mesenchymal differentiation. Ductal carcinoma in situ (DCIS) was accompanying an invasive component in twenty cases. Seventeen patients had lymph node metastasis. Twelve patients developed distant metastasis. Thirty patients were triple negative for hormone receptors. The mean follow-up period of the patients was 34 months. The estimated life expectancy was 116 months. All of the patients received chemotherapy and 28 patients received adjuvant radiotherapy. There was no correlation between tumor size and lymph node or distant metastasis in our series. Our findings are consistent with the literature.
\end{abstract}

Conclusion: Metaplastic breast carcinoma is a rare entity among breast carcinomas. Metaplastic carcinomas of the breast draw attention with the differences in their clinical course and the radiological and pathological heterogeneity.

Key Words: Metaplastic breast carcinoma, Survival, Immunohistochemistry

\section{INTRODUCTION}

Metaplastic breast carcinoma $(\mathrm{MBC})$ is a rare subtype and accounts for $0.2 \%$ to $5 \%$ of all breast carcinomas $(1,2)$. MBC was first described as a mammary carcinoma with mixed epithelial and sarcomatoid components by Huvos et al. in 1973 (3). The current (2012) World Health Organization (WHO) classification distinguishes five subtypes: low grade adenosquamous carcinoma, fibromatosis-like metaplastic carcinoma, spindle cell carcinoma, squamous cell carcinoma, and metaplastic carcinoma with mesenchymal differentiation (chondroid, osseous and other types of mesenchymal differentiation) $(2,4)$.

$\mathrm{MBC}$ is a distinct group of breast cancer, in which adenocarcinoma co-exists with a mixture of spindle cells and squamous, chondroid or bone-forming neoplastic cells, and differs from the classical invasive ductal or lobular carcinoma regarding its incidence, pathogenesis and prognosis $(1,5)$. These non-adenocarcinoma elements may be present as a microscopic foci or may dominate

(Turk Patoloji Derg 2020, 36:23-30)

Received : 29.04.2019 Accepted : 16.10.2019 the histologic pattern (5). The molecular mechanism of metaplastic carcinoma differs from other types of breast carcinomas, including basal-like breast carcinomas $(5,6)$.

It is suggested that upregulation of cancer stem cell (CSS) and epithelial-mesenchymal transition (EMT) genes might play a crucial role in the pathogenesis of $\mathrm{MBC}(1,5,7)$. EMT activators and CSS present especially in the non-glandular components of metaplastic carcinomas (8).

Due to its rarity, there is limited data correlating the imaging features with clinical presentation and the histopathologic features of MBC (9-11). Metaplastic cancers were previously radiologically defined as benign lesions $(9,10)$. Metaplastic carcinomas radiologically demonstrate benign features compared to invasive ductal carcinomas such as an oval or rounded shape, circumscribed margins and lack of malignant calcification (12).

MBC cases are typically negative for hormone receptors and do not exhibit Her2-neu overexpression $(1,13,14)$. Even though $\mathrm{MBC}$ is similar to triple negative breast

Correspondence: Bermal HASBAY

Department of Pathology, Başkent University

Dr. Turgut Noyan Application and Research Center, ADANA, TURKEY

E-mail: bermalhasbay@hotmail.com Phone: +905056247028 
cancers (TNBC) for receptor status, its molecular features are different and the clinical outcomes are even worse than for $\operatorname{TNBC}(1,14)$.

The aim of this study was to evaluate metaplastic carcinoma, a rare subtype of breast tumors, in terms of histopathological features, hormone receptor status, radiological features and treatment modalities.

\section{MATERIAL and METHODS}

A total of 38 MBC patients diagnosed between 2006 and 2018 at Baskent University Faculty of Medicine, Adana Research Hospital were included in the study. Ethics committee approval was received for this study from local ethics committee. A 12-year electronic data search was performed in the laboratory information system using the keywords "metaplastic carcinoma" plus "breast" in the diagnostic line. Thirty-eight cases met the criteria based on pathology reports and/or review of slides. Cases showing a metaplastic tumor component were included in the study. The patients were evaluated retrospectively for age, tumor size, tumor localization, histological grade, hormone receptor status (ER, PR, Her2-neu), American Joint Committee on Cancer (AJCC) Tumor, Lymph node status, Metastases (TNM) stage, progression, recurrence, survival, radiological features, surgery, and treatment modalities (adjuvant, neoadjuvant: chemotherapy and / or radiotherapy).

All of the cases were re-reviewed according to the 2012 WHO classification. Clinicopathological and demographic features were evaluated in detail. The pathologic diagnosis of MBC was made by two pathologists who were specialized in breast pathology and the sonographic and MRI features were assessed by two breast radiologists.

Immunohistochemical (IHC) assays were performed using monoclonal antibodies against ER (Clone EP1, Code M3643, Dako, Denmark) and PR (Clone Y85, 60-0056-7, Genemed, Germany) and Her2-neu (Code A0485, Dako, Denmark). ER and PR were prepared by taking positive and negative control tissues and using ready-to-use solutions in the Leica Bond Max device. We followed the ASCO and CAP recommendations for reporting the results of the IHC assays for ER, PR and Her2/neu. For ER and PR, all cases with at least $1 \%$ positive cells were considered as receptor positive $(5,15)$. The Allred score, which combines the percentage of positive cells and the intensity of the reaction, was used for ER-PR evaluation (16).

Her2-neu status can be determined by assessing protein expression on the membrane of tumor cells using IHC or by assessing the number of Her2-neu gene copies using in situ hybridization (ISH). The results for Her2-neu testing by IHC were reported according to the intensity and the percentage of positive staining in tumor cells $(0,1+, 2+$, $3+)$. Scores of 0 and $1+$ were considered as negative for Her 2-neu amplification. A score of $3+$ was considered as positive. A score of 2 was considered as equivocal and ISH was ordered for confirmation. Her 2 was considered to be amplified if the average Her2-neu copy number was $\geq 6$ signals/cells or the Her2/CEP 17 ratio was $\geq 2(5,17)$.

Statistical analysis was performed using the SPSS statistical package software (Version 17.0, SPSS Inc., Chicago, IL, USA). For each continuous variable, normality was checked by Shapiro-Wilk tests and by histograms. All numerical data were expressed as median values (Minimum-Maximum) or as proportions. Comparisons between groups were evaluated using the Mann-Whitney U test and the KruskalWallis test was used for the data not normally distributed.

The association with overall survival was analyzed using the Wald test and the log-rank test was used to examine their relationship when different variables were applied. The survival curve was plotted using standard KaplanMeier methodology.

Written consent was not obtained from the patients since the study was designed retrospectively and needed no consent.

\section{RESULTS}

The age of the patients ranged from 32 to 95 years and the mean age was $55.34 \pm 14.08$ years. The left breast was involved in 22 of the 38 (57.9\%) patients and the right breast in 16 (42.1\%). The mean tumor diameter was 4.48 $\pm 2.53 \mathrm{~cm}$ (max. 11.5, $\min .1 .8 \mathrm{~cm}$ ). Of the 38 cases, 7 were dead, 31 were alive. The mean age of the surviving patients was $53.74 \pm 12.98$ years (32-95) and the mean tumor size was $4.46(1.8-11.5) \mathrm{cm}$.

The estimated life expectancy of all patients was $116.3 \pm$ 10.2 months (95\% CI 96.3-136.3); 1-year survival 94.7\%; 3 -year survival $75 \%$; 5-year survival $75 \%$. While the estimated mean life expectancy of those with a tumor size $\leq 3 \mathrm{~cm}$ was $107.7 \pm 9.6$ months (95\% CI 88.9-126.5), for those with a tumor size $>3$ this was found to be $108.5 \pm$ 11.1 months (95\% CI 76.7-140.3) ( $\mathrm{p}=0.217$ log-rang test) (Figure 1). Therefore, tumor size below $3 \mathrm{~cm}$ or above $3 \mathrm{~cm}$ had no effect on survival.

The mean age of the dead patients was $62.43 \pm 17.57$ years (46-95) and their mean tumor size was $4(3-5) \mathrm{cm}$. Tumor histological grade was three for all patients. Eighteen of our patients underwent a mastectomy, of which 15 had axillary 
dissection and three had sentinel lymph node biopsy (SLNB). While one of the other 17 patients underwent only segmental mastectomy, 16 patients had segmental mastectomy and SLNB. A patient who was diagnosed with metastatic axillary lymph node at the age of 95 had only axillary lymph node sampling. Two patients were diagnosed from paraffin blocks as consultation cases and then were out of follow-up.

In the radiological examination of the patients, twentytwo patients underwent ultrasound where seventeen had malignant appearing solid masses, one had a mass of suspected malignancy, three had well-defined solid masses and one had an appearance compatible with mastitis. Eighteen patients had mammograms and MRI, where 12 showed solid masses of malignant appearance with

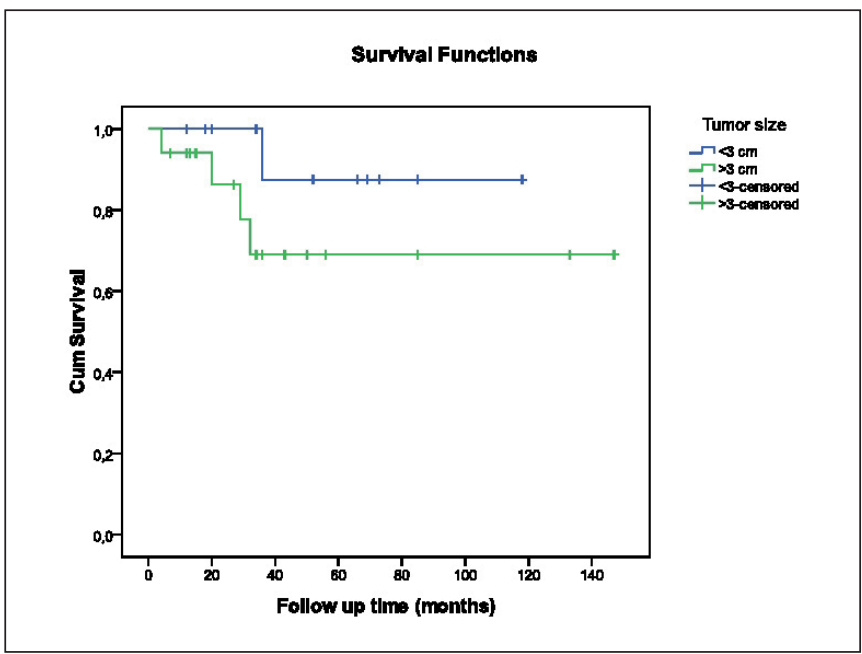

Figure 1: Relationship between tumor size and survival $(\mathrm{p}=0.217)$.

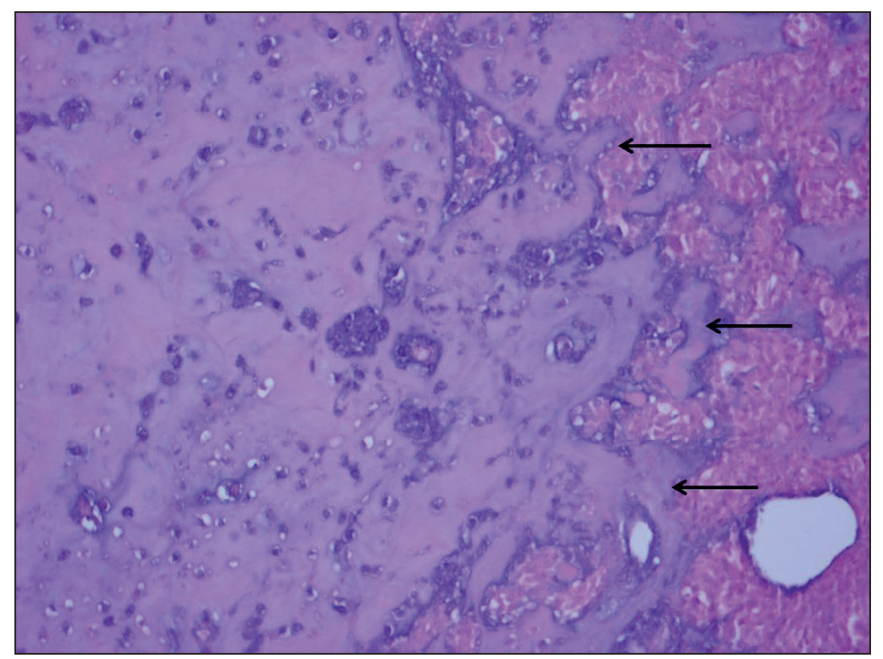

Figure 2: Epithelial component and chondroosseous areas (arrows) (H\&E; x200). irregular margins, asymmetric opacity and intermittent microcalcifications. In three cases with well-limited nodules on ultrasound, MRI showed solid lesions suspicious for malignancy.

Pathological results of the cases were as follows: pure epithelial carcinoma (IC-NST + squamous cell carcinoma) in 14 cases, mesenchymal component metaplastic carcinoma in 24 cases: (carcinoma including chondroosseous areas (Figure 2), mixed carcinoma (two pleomorphic sarcoma, one chondrosarcoma, one leiomyosarcoma), matrix-producing type carcinoma (Figure 3) and carcinomas with squamous and spindle cell areas cases). Ductal carcinoma in situ was accompanying an invasive component in twenty cases. Of these, the most common was the solid type, followed by the comedo and cribriform types. Axillary lymph nodes were observed to be benign in 18 of 35 patients (51\%), and metastatic in 17 of 35 (49\%). Among those with metastatic axillary nodes, 14 cases had $\mathrm{pN} 1$ and 3 cases had $\mathrm{pN} 2$. In terms of $\mathrm{pN}, 1$-year survival was $100 \%$ for $\mathrm{pN} 0,87.5 \%$ for $\mathrm{pN} 1,66 \%$ for $\mathrm{pN} 2$ with a significant $\mathrm{p}$ value $(0.009)$ (Figure 4). Twelve patients developed distant metastasis. Four patients had lung metastasis, two had supraclavicular lymph node metastasis, one had mediastinal lymph node metastasis, one had bone, liver and lung metastasis, two had bone metastasis and one had brain metastasis. Mean life expectancy of M0 (without metastasis) patients was $128.6 \pm 9.9$ months (95\% CI 109.1-148.0) while the figure for M1 (with metastasis) patients was $55.7 \pm 10.8$ month (95\% CI 34.6-76.9) ( $\mathrm{p}=0.077$ log-rang test). In our series of 38 cases, two patients had ER positive, one had ER and PR positive, one had ER and Her2-neu positive, four had only Her2-neu positive tumors and the remaining 30 had

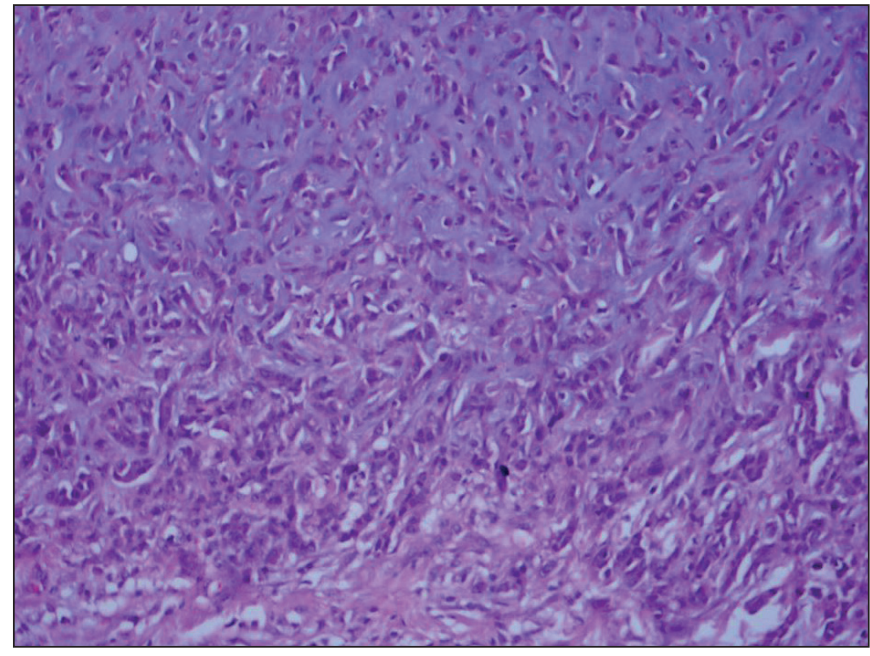

Figure 3: Matrix producing type carcinoma areas (H\&E; x200). 


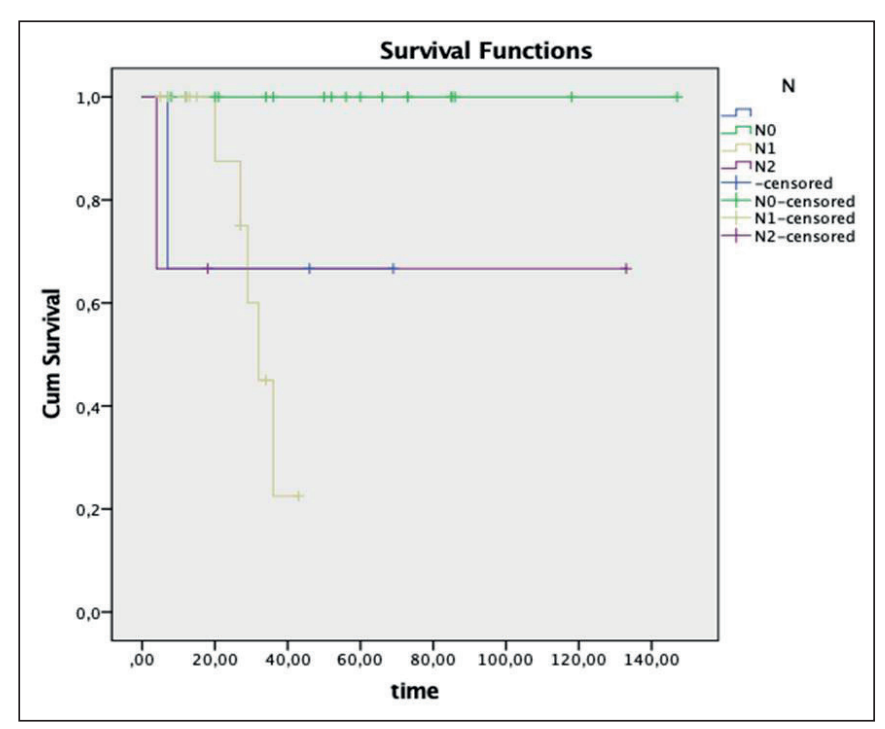

Figure 4: Relationship between pathological node $(\mathrm{pN})$ values and survival $(\mathrm{p}=0.009)$. tumors negative for all receptors. A summary of the hormone receptor profiles of the cases can be seen in Table I.

Mean follow-up period of patients was 34 months and ranged between 4 and 147 months. Five of the patients who died had pT2 and two had pTx tumors. All the patients who had pT1c, pT3 and pT4 survived. A detailed summary of dead patients is provided in Table II.

Among the patients that we followed-up, seven had chemotherapy (CT); three had chemotherapy, radiotherapy (RT) and Transtuzumab; two had CT, RT and Tamoxifen; and 24 had CT and RT. As a result, all patients were treated with $\mathrm{CT}$, and 28 of them also received RT. When viewed in terms of treatment, there was no difference in survival between CT or CT+RT and the p value was 0.391 . The clinico-pathological characteristics of the 38 patients with $\mathrm{MBC}$ are detailed in Table III.

Table I: Summary of hormone receptor positive cases.

\begin{tabular}{clccc}
\hline Cases & Diagnosis & ER & PR & Her 2-neu \\
\hline 1 & IC-NST + SCC & $30-40 \%$ Positive & Negative & Negative \\
\hline 2 & IC-NST + SCC & $40-50 \%$ Positive & Negative & Negative \\
\hline 3 & Containing squamous and spindle cell areas & $30-40 \%$ Positive & Negative & Score of 3 \\
\hline 4 & IC-NST + SCC & $60-70 \%$ Positive & $15-20 \%$ Positive & Negative \\
\hline 5 & IC-NST + SCC + containing spindle cell areas & Negative & Negative & Score of 3 \\
\hline 6 & IC-NST + SCC & Negative & Negative & Score of 3 \\
\hline 7 & IC-NST + SCC & Negative & Negative & Score of 3 \\
\hline 8 & IC-NST + SCC & Negative & Negative & Score of 3 \\
\hline
\end{tabular}

IC-NST: Invasive carcinoma-Carcinoma of no special type, SCC: Squamous cell carcinoma, ER: Estrogen receptor, PR: Progesterone receptor.

Table II: The features of the 7 dead patients.

\begin{tabular}{ccccccccc}
\hline Age & Tumor size & $\begin{array}{c}\text { Lymph } \\
\text { node stage }\end{array}$ & Metastasis & $\begin{array}{c}\text { Surgical } \\
\text { procedure }\end{array}$ & $\begin{array}{c}\text { Hormone } \\
\text { profile }\end{array}$ & $\begin{array}{c}\text { Follow-up } \\
\text { time (months) }\end{array}$ & Treatment \\
\hline 1 & 48 & $3.5 \mathrm{~cm}$ & $\mathrm{~N} 1$ & Lung & M + ALND & Negative & 20 & CT + RT \\
\hline 2 & 46 & $4 \mathrm{~cm}$ & $\mathrm{~N} 1$ & M0 & BCS + ALND & Negative & 29 & CT + RT \\
\hline 3 & 59 & Ready block & - & Lung & - & Negative & 7 & CT + RT \\
\hline 4 & 95 & - & N1 & M0 & ALND & Negative & 27 & - \\
\hline 5 & 54 & $4.5 \mathrm{~cm}$ & N2 & M0 & M + ALND & Negative & 4 & CT \\
\hline 6 & 58 & 5 & N1 & Bone + lung + liver & BCS & Negative & 32 & CT + RT \\
\hline 7 & 77 & 3 & N1 & Bone & M & Negative & 36 & CT \\
\hline
\end{tabular}

M: Mastectomy, BCS: Breast conserving surgery, ALND: Axillary lymph node dissection, SLND: Sentinel lymph node dissection, CT: Chemotherapy, RT: Radiotherapy. 
Table III: Clinico-pathological characteristics of 38 patients with MBC. [n (\%)]

\begin{tabular}{|c|c|}
\hline $\begin{array}{l}\text { Age group } \\
\leq 5014(36.8) \\
>5024(63.2) \\
\text { Mean age } 55.34(32-95)\end{array}$ & $\begin{array}{l}\text { Her2-neu } \\
\text { Positive } 5 \text { (13.2) } \\
\text { Negative } 33 \text { (86.8) }\end{array}$ \\
\hline $\begin{array}{l}\text { Tumor location } \\
\text { Right } 16(42.1) \\
\text { Left } 22(57.9)\end{array}$ & $\begin{array}{l}\text { pN } \\
\text { pN0 } 18(47.4) \\
\text { pN1 } 14(36.8) \\
\text { pN2 } 3(7.9) \\
\text { pN3 } 0(0) \\
\text { pNx } 3(7.9)\end{array}$ \\
\hline $\begin{array}{l}\text { Tumor size } \\
\leq 3 \mathrm{~cm} 13(34.2) \\
>3 \mathrm{~cm} 17(44.7) \\
\text { Unknown } 8(21.1) \\
\text { Mean size } 4.48 \mathrm{~cm}(1.8-11.5 \mathrm{~cm})\end{array}$ & $\begin{array}{l}\text { Tumor subtype } \\
\text { IC-NST + SCC } 14 \text { (36.8) } \\
\text { Mixed carcinoma } 8(21.1) \\
\text { Pleomorphic sarcoma } \\
\text { Chondrosarcoma } \\
\text { Leiomyosarcoma } \\
\text { Squamous and spindle cell areas } \\
\text { Matrix producing } 4(10.5) \\
\text { MMC 12 (31.6) }\end{array}$ \\
\hline $\begin{array}{l}\text { pT } \\
\text { pT1 } 3(7.9) \\
\text { pT2 } 20(52.6) \\
\text { pT3 } 4(10.5) \\
\text { pT4 } 3(7.9) \\
\text { Unknown } 8(21.1)\end{array}$ & $\begin{array}{l}\text { Metastasis } \\
\text { Lung } 4 \text { (10.5) } \\
\text { Lymph node } 3(7.9) \\
\text { Bone+liver+lung } 1 \text { (2.6) } \\
\text { Bone } 2(5.3) \\
\text { Brain } 1(2.6) \\
\text { No metastasis } 27(71.1)\end{array}$ \\
\hline $\begin{array}{l}\text { Nuclear grade } \\
\text { G1 } 0 \\
\text { G2 } 0 \\
\text { G3 } 38(100)\end{array}$ & $\begin{array}{l}\text { Surgery } \\
\text { Mastectomy } 18(47.4) \\
\text { and ALND } 15 \\
\text { and SLND } 3 \\
\text { Segmental mastectomy } 17 \text { (44.8) } \\
\text { and SLND } 16 \\
\text { ALND } 1(2.6) \\
\text { Unknown } 2(5.2)\end{array}$ \\
\hline $\begin{array}{l}\text { Estrogen receptor (ER) } \\
\text { Positive } 4(10.5) \\
\text { Negative } 34(89.5)\end{array}$ & $\begin{array}{l}\text { Systemic therapy } \\
\text { CT only } 7(18.4) \\
\text { CT + RT } 24(63.1) \\
\text { CT + RT + TTZ } 3(7.9) \\
\text { CT + RT + TMX 2 (5.3) } \\
\text { Not followed } 2 \text { (5.3) }\end{array}$ \\
\hline $\begin{array}{l}\text { Progesterone receptor }(\mathbf{P R}) \\
\text { Positive } 1(2.6) \\
\text { Negative } 37(97.4)\end{array}$ & $\begin{array}{l}\text { Final status } \\
\text { Alive } 31(81.5) \\
\text { Ex } 7(18.5)\end{array}$ \\
\hline
\end{tabular}




\section{DISCUSSION}

Metaplastic breast carcinoma has a poor prognosis and is usually triple negative. MBC pathologically comprises different histologic components of both epithelial and mesenchymal origins $(1,2)$. It constitutes between $0.2 \%$ and $5 \%$ of all breast cancers and is generally observed in the sixth decade of life (2). The mean age of our patients was 54 years, which was consistent with the literature. Patients with $\mathrm{MBC}$ usually present with large size, higher grade and hormone receptor negative tumors $(13,14)$. Similarly, mean tumor size of our cases was $4.48(1.8-11.5) \mathrm{cm}$, all of them were histologically grade 3 , and $79 \%$ had a negative hormone profile. Three of the cases were pT1c, 20 were pT2, four were pT3, and three were pT4. Another 7 patients were evaluated as $\mathrm{pTx}$ because three of them were sampled after chemotherapy, and four were diagnosed using preformed archival paraffin blocks of different centers. Even though $\mathrm{MBC}$ is usually reported to be an aggressive tumor with fewer nodal metastases $(1,14)$, there are some studies demonstrating a frequency of nodal metastases of up to $21 \%$ to $64 \%(1,18,19)$. In our series, 17 patients $(49 \%)$ had axillary lymph node metastasis which was consistent with the literature. Thirteen of seventeen patients with lymph node metastasis had pure epithelial component, one patient had carcinosarcoma and three patients had metaplastic carcinoma with mesenchymal differentiation.

Ductal carcinoma in situ may be visible adjacent to metaplastic carcinoma at a rate of $11 \%$ to $65 \%$. The presence of DCIS strongly supports the diagnosis of metaplastic carcinoma (20). In our series, 20 of 38 (52.14\%) cases had DCIS which was also consistent with the literature.

$\mathrm{MBC}$ is a heterogeneous disease with different subgroups. According to the 2012 WHO classification, it is divided into 5 groups: low grade adenosquamous carcinoma, fibromatosis-like metaplastic carcinoma, squamous cell carcinoma, metaplastic carcinoma with mesenchymal differentiation (chondroid, osseous, other types of mesenchymal differentiation) and spindle cell carcinoma $(2,4)$. We did not observe any low grade adenosquamous carcinoma or fibromatosis-like metaplastic carcinoma in our series.

Several hypotheses have been suggested for the etiopathogenesis of MBC. The first one is the 'cancer stem cell hypothesis', which describes the cells that have the capacity to self-renew and differentiate into different cell types $(21,22)$. The carcinomatous and sarcomatous components may develop from separate progenitor cells or both components may develop from multipotential progenitor cells. One other theory is related to the changes in the expression of membrane proteins involved in cell polarity and in the tight linkage functions between cells which is called "Claudin" (22).

Optimal treatment of MBC is in the same way as IC-NST. Surgery is the main curative approach. Mastectomy or breast conserving surgery have been the most commonly performed procedures $(23,24)$. All of the patients received surgical treatment in our series. The most common surgical procedure was the modified radical mastectomy, which was performed in 18 patients. Seventeen patients had breast conserving surgery. All of our patients were treated with chemotherapy after surgery and 28 of them received additional radiotherapy.

Hormonal therapy generally has no role in the management of patients with MBC. There is a high incidence of hormone receptor negativity as well as lower Her2-neu overexpression in MBC. In our series of 38 patients, only four were hormone positive and five were Her2-neu positive, and the rest of them were negative hormone receptors. Her2-neu overexpression rate has been variable in the literature, between $2 \%$ and $26 \%(13,14,20,25)$. ER positivity varies between $6 \%$ and $12 \%$ in various studies (20). In our series, only 5 of $38(13 \%)$ cases had positive Her2-neu and 4 of $38(10.52 \%)$ cases had positive ER which is also consistent with the literature. In the study of Rakha et al., these three markers were more often positive in squamous carcinomas (13). In our cases, all ER and Her2-neu positive cases were metaplastic carcinomas with squamous cell carcinoma (Table I). Tamoxifen was added to the treatment of ER positive patients, and Transtuzumab for Her2-neu positive patients.

The median follow-up for MBC patients was 34 (range 4-147) months. Among patients who developed distant metastasis during follow-up, the lung was the most common site as seen in four patients. Bone metastasis was seen in two patients, supraclavicular lymph node involvement in two patients, mediastinal lymph node metastasis in one patient, both bone, liver and lung metastasis in one patient and brain metastasis in one patient.

Diagnosis of MBC cannot rely on imaging features alone. Core needle biopsy and aspiration cytology may aid in the pre-operative diagnosis, but the probability of misdiagnosis would increase in the presence of hemorrhage or necrosis due to inadequate sampling or a poor choice of puncture region (12,26). Excisional biopsy is the gold standard without doubt and should be used in all patients prior to surgery. 
If core biopsy shows the appearance of a pure malignant mesenchymal tumor, this may be a primary malignant mesenchymal tumor of the breast, a malignant phyllodes tumor or a metaplastic carcinoma with mesenchymal differentiation. Once the hematoxylin and eosin stained slides are examined, a decisioni can be made as follows: If the tumor was pure sarcomatoid, then it had to express at least 2 epithelial markers in the immunohistochemistry analysis (cytokeratin 5/6, high molecular weight cytokeratin, P63, pancytokeratin, CK7) for the diagnosis of MBC. According to the histopathological appearance of the sarcomatoid component, it is possible to add S-100, Smooth Muscle Actin (SMA), CD68, Calponin, and Desmin. It is more appropriate to provide a definite diagnosis on excisional biopsy specimens. In the majority of cases, the transition foci between MBC and IC-NST were only observed following surgical biopsies $(12,26)$. Metaplastic carcinoma should also be considered when a spindle cell lesion is seen on a breast tru-cut biopsy. Extensive sampling from the surgical biopsy and an immunohistochemical examination should therefore be performed to avoid misdiagnosis.

The differential diagnosis between $\mathrm{MBC}$, sarcoma and phylloides tumor is important as SLNB sampling is mandatory for $\mathrm{MBC}$, but not for others.

In conclusion, $\mathrm{MBC}$ is a rare entity among breast carcinomas. It is an aggressive tumor that is more likely to present with worse prognostic indicators such as tumor size and stage. However, low-grade adenosquamous carcinoma in this group has a good prognosis.

The diagnosis of $\mathrm{MBC}$ is difficult in some cases and requires rigorous use of immunohistochemistry. Most of the cases present with poor prognostic indicators and show lack of expression of hormone receptors as well as Her2-neu. It is evident that more studies are needed to understand the true biologic potential of this tumor compared with other forms of breast carcinoma. In conclusion, our findings are consistent with the literature. Prospective multi-center wide scale studies should be carried out in the future to cast light on the clinical and pathologic aspects of MBC.

\section{CONFLICT of INTEREST}

No conflict of interest was declared by the authors.

\section{FUNDING}

The authors declared that this study has received no financial support.

\section{REFERENCES}

1. Aydıner A, Sen F, Tambos M, Çiftci R, Eralp Y, Saip P, Karanlik H, Fayda M, Kucucuk S, Onder S, Yavuz E. Metaplastic breast carcinoma versus triple-negative breast cancer: Survival and response to treatment. Medicine. 2015; 94:e2341.

2. Sunil RL, Ian OE, Stuart JS, Puay HT, March JV. WHO Classification of Tumours of the Breast. 4nd ed. Sunil RL, editor. Lyon: IARC; 2012. 48-53.

3. Huvos AG, Lucas JC, Foote FW. Metaplastic breast carcinoma Rare form of mammary cancer. N Y State J Med. 1973;73:107882.

4. Han M, Salamat A, Zhu L, Zhang H, Clark BZ, Dabbs DJ, Carter GJ, Brufsky AM, Jankowitz RC, Puhalla SL, Johnson RR, Soran A, Steiman JG, McAuliffe PF, Diego EJ, Bhargava R. Metaplastic breast carcinoma: A clinical- pathologic study of 97 cases with subset analysis of response to neoadjuvant chemotherapy. Modern Pathology. 2019; 32:807-16.

5. Salah F, Gerges AD, Heba EE, Henney A, Saqed A. Metaplastic breast carcinoma: Analysis of 31 cases from a single institute. J Egypt Natl Canc Inst. 2017;29:141-5.

6. Hennessy BT, Gonzalez -Angulo AM, Stemke-Hale K, Gilcrase MZ, Krishnamurthy S, Lee JS, Fridlyand J, Sahin A, Agarwal R, Joy C, Liu W, Steivers D, Baggerly K, Carey M, Liuch A, Monteagudo C, He X, Weigman V, Fan C, Palazzo J, Hortobagui GN, Nolden LK, Wang NJ, Valero V, Gray JW, Perou CM, Mills GB. Characterization of a naturally occurring breast cancer subtype enriched in epithelial-to-mesenchymal transition and stem cell characteristics. Cancer Res. 2009; 69:4116-24.

7. Lien HC, Hsiao YH, Lin YS, Yao YT, Juan HF, Kuo WH, Hung MC, Chang KJ, Hsieh FJ. Molecular signatures of metaplastic carcinoma of the breast by large scale transcriptional profiling: Identification of genes potentially related to epithelialmesenchymal transition. Oncogene. 2007;26:7859-71.

8. Zhang Y, Toy KA, Kleer CG. Metaplastic breast carcinomas are enriched in markers of tumor-initiating cells and epithelial to mesenchymal transition. Mod Pathol. 2012;25:178-84.

9. Langlands F, Cornford E, Rakha E, Dall B, Gutteridge E, Dodwell D, Shaaban AM, Sharma N. Imaging overview of metaplastic carcinomas of the breast: A large study of 71 cases. Br J Radiol. 2016;89:20140644.

10. Bilgen IG, Memiş A, Üstün EE, Zekioğlu O, Ozdemir N. Metaplastic carcinoma of breast: Clinical, mammographic and sonographic findings with histopathologic correlation. AJR Am J Roentgenol. 2002;178:1421-5.

11. Choi BB, Shu KS. Metaplastic carcinoma of the breast: Multimodality imaging and histopathologic assessment. Acta Radiol. 2012;53:5-11.

12. Bian T, Lin Q, Wu Z, Cui C, Qi C, Li L, Su X. Metaplastic carcinoma of the breast: Imaging and Pathological features. Oncol Lett. 2016;12(5):3975-80.

13. Rakha EA, Coimbra NM, Hodi Z, Juneinah E Ellis IO, Lee AS. Immunoprofile of metaplastic carcinomas of the breast. Histopathology. 2017;70:975-85. 
14. El Zein D, Hughes M, Kumar S, Peng X, Oyasiji T, Jabbour $\mathrm{H}$, Khoury T. Metaplastic carcinoma of the breast is more aggressive than tripple- negative breast cancer: A study from a single institution and review of literature. Clin Breast Cancer. 2017;17:382-91.

15. Hammond ME, Hayes DF, Dowsett M, Allred DC, Hagerty KL, Badve S, Fitzgibbons PL, Francis G, Goldstein NS, Hayes M, Hicks DG, Lester S, Love R, Mangu PB, McShane L, Miller K, Osborne CK, Paik S, Perlmutter J, Rhodes A, Sasano H, Schwartz JN, Sweep FC, Taube S, Torlakovic EE, Valenstein P, Viale G, Visscher D, Wheeler T, Williams RB, Wittliff JL, Wolff AC. American Society of Clinical Oncology/College of American Pathologists guideline recommendations for immünohistochemical testing of estrogen and progesterone receptors in breast cancer. Arch Pathol Lab. Med. 2010;134:907-22.

16. Allred DC. Problems and solutions in the evaluation of hormone receptors in breast cancer. J Clin Oncol. 2008;26:2433-5.

17. Wolff AC, Hammond ME, Hicks DG, Dowsett M, McShane LM, Allison KH, Allred DC, Bartlett JM, Bilous M, Fitzgibbons P, Hanna W, Jenkins RB, Mangu PB, Paik S, Perez EA, Press MF, Spears PA, Vance GH, Viale G, Hayes DF. Recommendations for human epidermal growth factor receptor 2 testing in breast cancer: American society of Clinical Oncology-College of American Pathologists (ASCO/CAP) Clinical practise Guideline Update. J Clin Oncol. 2013;31:3997-4013.

18. Pezzi CM, Patel-Parekh L, Cole K, Franko J, Klimberg VS, Bland $\mathrm{K}$. Characteristics and treatment of metaplastic breast cancer: Analysis of 892 cases from the National Cancer Data Base. Ann Surg Oncol. 2007;14:166-73.
19. Esbah O, Turkoz FP, Turker I, Durnali A, Ekinci AS, Bal 0, Sonmez OU, Budakoglu B, Arslan UY, Oksuzoglu B. Metaplastic breast carcinoma: Case series and review of the literatüre. Asian Pac J Cancer Prev. 2012;13:4645-9.

20. Hoda SA, Brogi E, Koerner FC, Rosen PP. Rosen's Breast Pathology. 4th ed. 2014. 547-99.

21. Reya T, Morrison SJ, Clarke MF, Weissman IL. Stem cell, cancer and cancer stem cell. Nature. 2001; 414:105-111.

22. Onur G. Metaplastik Meme Karsinomlarında Kök Hücre belirteçleri (ALDH1, CD44, CD24) ve Hücreler Arası Sıkı Bağlantı Proteinlerinin (CLAUDİN 3, CLAUDİN 4 ve CLAUDİN 7) Ekspresyonlarının Tanı, Prognoz ve Moleküler Alt Tipler ile İlişkisi. 2015 Uzmanlık tezi.

23. Ghosh M, Muneer A, Trivedi V, Mandal K, Shubham S. Metaplastic carcinoma breast: A clinical analysis of nine cases. J Clin Diagn Res. 2017;11(8):XR01-XR03.

24. Gultekin M, Eren G, Babacan T, Yildiz F, Altundag K, Guler N, Ozisik Y, Yazici G, Hurmuz P, Gurkaynak M. Metaplastic breast carcinoma: A heterogeneous disease. Asian Pac J Cancer Prev. 2014;15:2851-6.

25. Song Y, Liu X, Zhang G, Song H, Ren Y, He X, Wang Y, Zhang T, Sun S, Liang X, Sun Q, Pang D. Unique clinicopathological features of metaplastic breast carcinoma compored with invasive ductal carcinoma and poor prognostic indicators. World Journal of Surgical Oncology. 2013;11:1-9.

26. Leddy R, Irshad A, Rumboldt T, Cluver A, Campbell A, Ackerman S. Review of metaplastic carcinoma of the breast: Imaging findings and pathologic features. J Clin Imaging Sci. 2012;2:21. 